\title{
TENURE STATUS IN LIFE CYCLE COHORTS IN POLAND
}

\author{
Anna Matel \\ University of Bialystok \\ e-mail:a.matel@uwb.edu.pl
}

Poland is characterized by a relatively high level of homeowners ( $84 \%$ of population in 2018). The preference for ownership, as well as financial possibilities, are not balanced throughout the entire life cycle of a household. The scale of these differences, as well as the tendency to change over time, remains unknown. The subject of conducted research is to indicate how the structure of the tenure status of Poles changes over the life cycle of a household. This publication proposes the division of the household life cycle into the stages of formation, stabilization and reduction. The research on the structure of the tenure status of Poles was conducted for the period of 2006-2018. The analysis showed that, while the share of owner-occupiers increased significantly in Poland in the years 2006-2018, at the stage of forming a household rent begins to prevail. What is more, young people are more likely to choose market rent, and relocation to private housing is associated with having children or getting married. At the same time, there is no tendency to relocate to rented flats at the stage of household reduction in Poland.

Key words: tenure status, housing market, ownership, tenants, life cycle.

JEL Classification: R21, D01.

Citation: Matel, A. (2021). Tenure status in life cycle cohorts in Poland. Real Estate Management and Valuation, 29(3), 01-12.

DOI: https://doi.org/10.2478/remav-2021-0017

\section{Introduction}

Tenure status and tenure choices of the population are very important elements of housing choice and housing market. Amazingly little research has been carried out in the field of shaping this structure in Poland. This paper analyzes the tenure choice decisions in the context of household formation in the Polish market. Tenure status implies the current situation of the household in relation to the way of satisfying housing needs and having a housing stock. Its simple classification distinguishes owneroccupiers and tenants. In addition, Eurostat (Methodological..., 2015) divides the owners into: paying and not paying mortgage and tenants into: renters of the flat at market and reduced price (including using free accommodation).

Poland is among countries with a relatively high level of housing ownership. Although this phenomenon is observed in most European economies, it varies greatly from country to country. So, while in Germany and Austria the share of owners does not exceed $60 \%$, in Croatia, Slovakia and Romania it is over $90 \%$ of the population (Eurostat, 2020). At the same time, in the period for which comparable data are available at the European level (2006-2018), changes in the ownership structure in individual countries are observed. So, while for example in Czech Republic, Netherlands or Slovakia a slight growth was observed, in other countries, such as Denmark, Estonia or Slovenia, this process has been reversed. Poland is one of the few countries in the European Union in which the share of owners is constantly growing. In 2005, it amounted to $72.7 \%$ and, apart from slight fluctuations, it grew systematically reaching the level of $84 \%$ in 2018. As in most of the 2004 enlargement countries (including the Czech Republic, Lithuania, Latvia, Estonia), in Poland too there is a growing share of 
homeowners with a mortgage. The growth of the ownership sector in Poland does not take place at the expense of a decline in the private, but public rental sector (Fig. 1).

The changing situation on rental market in Poland is connected to shifting trajectories from the dualist rental system (largely unregulated profit-driven private rental market and tightly controlled public rental sector) into a unitary one (Rubaszek, 2019). Is seems that the rental market in Poland is still changing, which is reflected in the declining percentage of tenants at reduced price. What is more, the very high percentage of homeowners and, as a result, the current tenure structure in Poland, is mainly due to the transfer of public rental housing into private hands, which took the form of a massive sale to sitting tenants who - citing Lux and Sunega (2014) - obtained housing wealth almost or wholly free of charge.

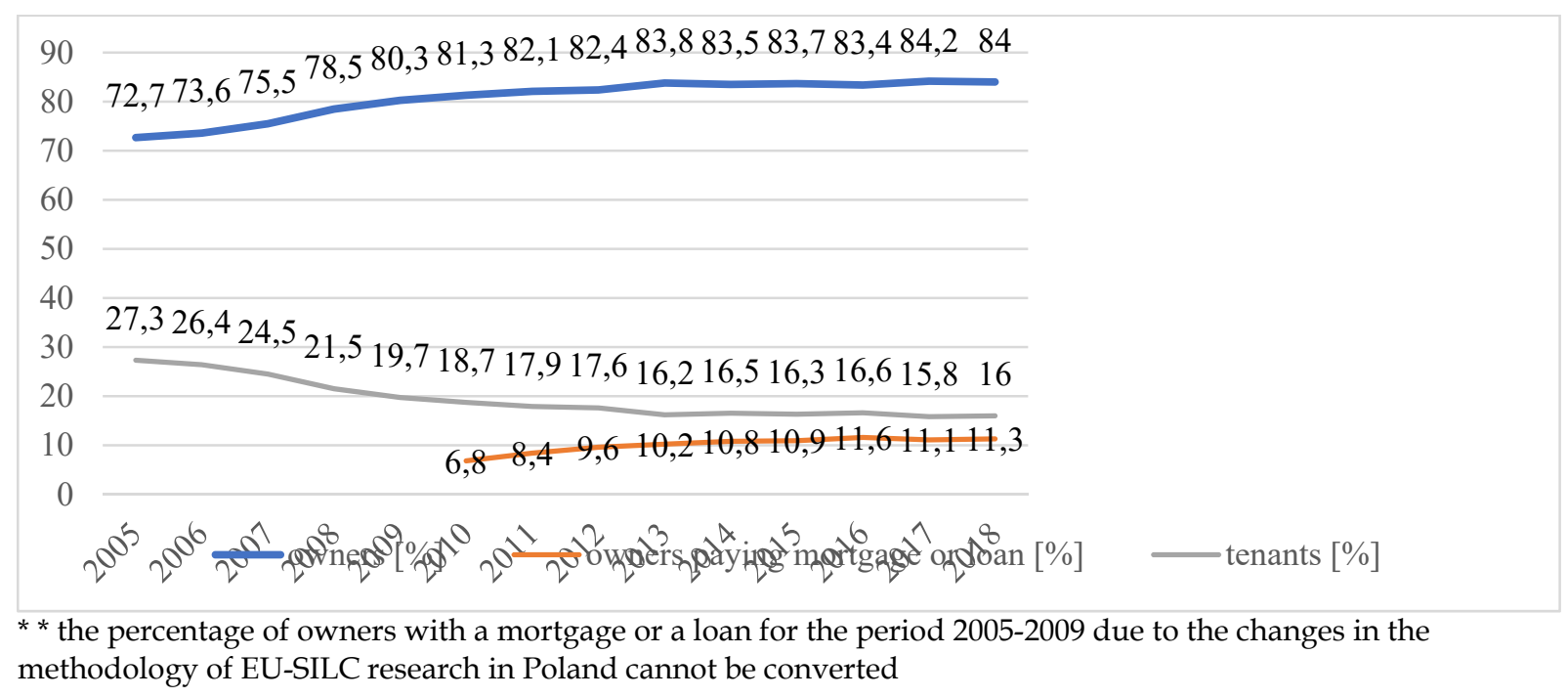

Fig. 1. Distribution of population by selected tenure status in Poland in 2005-2018. Source: own elaboration based on: data for 2005-2009: internal materials of the Central Statistical Office, data for 2010-2018: Eurostat, 2020.

Both data and research (e.g. Rubaszek \& Czerniak 2017) indicate that we are able to observe, in Poland, a clear preference of households to be owners-occupiers rather than tenants. According to Rubaszek (2019), such strong preferences are enchanced by the belief that homeownership in Poland is the only way to provide a safe place for the family and to really "feel at home". The preference for ownership is probably not balanced in all age and life-cycle clusters, though is unknown to what extent. This is because, over the life cycle, households experience significant economic changes, concerning, e.g., the income level or occupational situation, as well as socio-demographic changes, concerning marital status, having children, children moving out, divorce or the death of a spouse. These changes lead to changes in preferences (e.g. Barrios et al., 2013) and the possibility of achieving a specific tenure status.

Moreover, it can be expected that transitions in the last decade's events have changed the structure of the tenure status of households, especially in the face of the past economic crisis (2007 and the following) and the dynamic growth of the housing market in the recent years (2016 and the following). In the research, data covering the years 2006, 2010, 2014 and 2018 were used. The study therefore covered the period of the boom before the housing market crisis (2006), the period of increasing crisis in the financial markets (2010), the period of return to the upward trend (2014) and the housing boom (2018). The changes in the housing status of young people entering first ownership are particularly interesting. According to Lennartz et al. (2016) diminishing access to homeownership for young people (18-34) was observed in affected countries, which resulted in a growing share of coresiding adult children. On the other hand, after the crisis period in Poland, there was a strong political promotion and support for homeownership by implementing the programs "Family on Its Own" and "A Place to Live for the Young". The total impact of these changes on the structure of the tenure status of households at the household formation stage remains unknown.

The conducted study sought to answer the following research questions: (1) How is the structure of the tenure status of households in Poland different in particular stages of the household life cycle? (2) 
How did the structure of tenure status of households in Poland change in the years 2006-2018 in particular stages of the life cycle?

The structure of the article is as follows. The first section is an introduction, presenting the general idea of the study. The next section focuses on previous research. Subsequently, data and methods are discussed. In the next section, the research results are presented. Microdata from European Union Statistics on Income and Living Conditions (EU-SILC) was used.

\section{Literature review}

In the literature, many factors have been found to influence investment in homeownership. When comparing the ownership structure of housing between countries (e.g. Bazyl, 2009; Andrews \& Sánchez, 2011), institutional factors, the history of privatization of housing stocks, implemented housing policy, tenant protection law (Andrews \& Sánchez, 2011; Cuerpo et al., 2014) and cultural differences (Edgar et al., 2007) are usually found to be crucial. In the analysis of differences in the tenure status of households within one economy, the key issues are economic factors and the sociodemographic situation of the household (Matel, 2019). In Poland, as in other countries (Gyourno \& Linneman, 1997; Andersen, 2011), changes in housing preferences and choices are observed along with changes in household parameters such as age, having children, marriage, divorce or the death of a spouse. These variables actually describe the life cycle. On the one hand, it is an expression of changes in housing needs (growing need for stability, decreasing job mobility), on the other, - the ability to overcome financial barriers (creditworthiness, professional stability).

In the literature, there are many approaches to a household life cycle. For example, in consumption research, phases of the family life are determined with regard to marital status, having and living together with children, and age (Rudnicki, 2012). On this basis, Rudnicki (2012, p. 101) specifies 12 possible phases of the life cycle of a modern family.

The basic indicator of the life cycle is the age of the head of the household. Homeownership is generally less likely among younger householders (Gyourno \& Linneman, 1997; Arrondel et al., 2010). According to Barrios et al. (2013), for Spanish households, this could not be explained only by the development in the economic resources of families during the life cycle. This indicates that, with age, the preferences regarding the form of ownership of the flat change as well. However, studies carried out on the Belgian market have shown that this increase occurs only until reaching a certain age (Xhignesse, 2014). In some societies, there is a decline in ownership in the older age groups. Elderly people are increasingly opting for renting, which may result from lower housing needs, high maintenance costs, and the desire to live closer to children (Disney et al., 1995).

Changes in housing choices that can be observed with age are associated with key family formation events, such as: childbirth or partnership formation (Dieleman \& Everaers, 1994; Kendig, 1984; Mulder \& Wagner, 1998).

The first key event affecting the housing needs and preferences of young people is entering into a relationship (Kemp \& Keoghan, 2001). According to Feijten (2005) and Thomas and Mulder (2016), this influence concerns settled relationships. In research, this is expressed by the difference observed between the housing situation of single individuals from a co-residential partnership and married ones. The reason for this may be both, an increase in the household income after marriage, which gives greater opportunities to accumulate the resources required to purchase a dwelling, as well as striving to meet the need for security and stability.

Homeownership is also related to parenthood. Coulter (2018) and McKee (2012) stated that this is due to strong pressure to find a permanent home. At the same time, the purchase of a flat, renovation work and moving house require a considerable amount of money, which parents often cannot afford at the same time while paying for the maintenance of a child. What is more, many new mothers reduce their working hours (Flynn, 2017). Such a relation explains why couples try to enter homeownership before childbirth and, thus, potentially delay childbearing when homeownership is relatively less affordable (McKee et al., 2017).

A life event that significantly changes housing preferences and needs is the reduction of the household. This occurs as a result of children moving out, divorce or the death of a spouse. These events cause a decrease in demand for living space. The reduction associated with the breakup of a relationship - similarly to retirement - makes the expenses related to housing maintenance more burdensome. In order to reduce them, it is possible to reduce the living space used, and actually adapt 
it to the current needs (Coulter, 2018). Declarative research shows, however, that this is not a popular solution in Poland, because seniors want to stay in their homes as long as possible, which is consistent with the concept of aging in place (Strączkowski \& Baruta, 2018).

When analyzing the changes in housing status over the life cycle of a household, it should also be taken into account that they probably differ between economies and change under the influence of the current economic situation in the country.

The structure of tenure status in the life cycle could differ across economies mainly due to its historical background and cultural patterns. For example, due to Bayrakdar et al. (2019) in Britain, first-time homeownership is tightly synchronized with partnership formation, while, in Germany, these transitions usually occur later in life cycle and are more closely associated with the arrival of children. These differences are mainly explained by weaker aspirations and weaker incentives to enter homeownership in Germany (Bayrakdar et al., 2019). In this respect, Poles seem to be more like British people. Both exhibit strong aspirations to be the homeowner (Rubaszek \& Czerniak, 2017), and the unfavourable relationship of the rent of the flat to potential loan instalments increase the desire to quickly come into the ownership of the flat.

What is more, the structure of tenure status in the life cycle could differ due to current conditions of the economy. According to Capeau et al. (2003), the higher the tax rate, the more households postpone homeownership or choose to be lifelong tenants. Similarly, dwelling prices and the interest rate on mortgages have a negative impact on early homeownership. This is particularly evident in delaying the decision to relocate to a property flat after having a child (Flynn, 2017). On the other hand, research by Andersen (2011) indicates that, in Denmark, new generations have much stronger preferences for homeownership. In Poland, in recent years, housing policy programs have been implemented to increase the availability of a flat for families (Family on its own) and for young people in general (A Place to Live for the Young). This, in turn, may result in the acceleration of the process of entering into the ownership of a flat among the Polish population, although the impact is probably not even throughtout all stages of the household's life cycle.

\section{Data and Methods}

The conducted research aimed at determining changes in the structure of the housing status of households in individual stages of the life cycle in Poland in the years 2006-2018. The analysis used microdata from European Union Statistics on Income and Living Conditions (EU-SILC). Due to the low dynamics of changes in the structure of tenure status in the economy, the research was conducted at four-year intervals for the years 2006, 2010, 2014 and 2018.

Tenure status categories, which could be distinguished based on the EU-SILC database, were analysed. Subjected tostudies were: (1) the share of homeowners and tenants in all households, (2) the share of tenants paying the market rate of all tenants (3) the share of homeowners paying mortgage of all homeowners (Methodological.., 2015). The expression "homeowner household" refers to a situation in which the owner of the flat is a member of the household. The owner is considered as a homeowner without a mortgage when he / she has no more mortgage to pay for his / her main dwelling (paying loans for other dwelling is not considered). Rent at market price applies to all situations where the tenant pays the market price for renting or subletting a flat (Methodological Guidelines..., 2015).

In the study, cross-tables with the use of the $\chi^{2}$ test and quota coefficient were used, as well as a test for two fractions and an analysis of correspondence.

The challenge in the conducted research was to specify the stages of the household life cycle. It can be seen that such distinctions are most often based on the age criterion (e.g. Gyourno \& Linneman, 1997. Barrios et al., 2013). According to data for Poland, this is an important indicator of changes in tenure choices (Table 1). Nevertheless, an analysis of the literature indicates that relocation to private housing is strongly associated with breakthrough events in the household's life cycle, which usually occur at a certain age range, including: entering into a relationship or its break-up (Byrne et al., 2018; Andersen, 2011) and having children (Coulter, 2018; Mckee, 2012). In relation to Polish society, this is also confirmed by statistical data (Tables 2 and 3 ).

The share of owners in the entire study period was significantly lower among people under the age of 35 than in other age clusters ( $p<0.000$ ). In 2018 , it was over $60 \%$, with an index of $84-85 \%$ in other age clusters. There were no significant differences in the share of homeowners between the second and third age clusters (except for 2006). This indicates the lack of a tendency among Poles to relocate 
to rented flats in old age.

The share of homeowners varied significantly in particular groups of marital status (Table 2). In the entire analyzed period, the share of single persons was significantly lower than that of married and widowed ones $(p<0.001)$. Similarly, the share of homeowners among divorced or separated persons, as well as widows / widowers in the entire period was significantly lower than among married ones ( $p<0.001)$. In general, there is a noticeable tendency to increase the share of homeowners after marriage and a decline after its dissolution, with the decrease being stronger in the event of a divorce or separation than in the event of the death of one of the spouses. This relationship is quite intuitive. In the event of divorce, two separate households are created.

Table 1

Share of homeowners in clusters by the age of the head of the household in Poland in 2006-2018

\begin{tabular}{lllll}
\hline Age cluster & 2006 & 2010 & 2014 & 2018 \\
\hline do 35 & 60.3 & 65.8 & 64.7 & 60.6 \\
\hline $\mathbf{3 6 - 6 5}$ & 74.6 & 83.5 & 85.5 & 84.0 \\
\hline powyżej 65 & 78.3 & 82.1 & 84.5 & 85.5 \\
\hline
\end{tabular}

Source: own elaboration basing on EU-SILC microdata.

Table 2

Share of homeowners by marital status of the head of household in Poland in 2006-2018

\begin{tabular}{lllll}
\hline Group & $\mathbf{2 0 0 6}$ & $\mathbf{2 0 1 0}$ & $\mathbf{2 0 1 4}$ & $\mathbf{2 0 1 8}$ \\
\hline never married & 63.6 & 68.9 & 69.5 & 63.5 \\
\hline married & 77.1 & 84.9 & 86.4 & 87.0 \\
\hline separated/divorced & 57.7 & 66.9 & 72.9 & 67.4 \\
\hline widower & 73.5 & 78.4 & 81.3 & 82.2 \\
\hline
\end{tabular}

Source: own elaboration basing on EU-SILC microdata.

In Poland, the relationship between having children and owning a flat differs significantly across age clusters (Table 3 ).

Table 3

Share of homeowners by child's residence in the household in particular age clusters in Poland in 2006-2018

\begin{tabular}{|c|c|c|c|c|}
\hline Household: & 2006 & 2010 & 2014 & 2018 \\
\hline \multicolumn{5}{|c|}{ head of the household is less than 35} \\
\hline With children & 61.8 & 68.3 & 69.1 & 68.7 \\
\hline Without children & 57.5 & 60.7 & 56.1 & 48.3 \\
\hline \multicolumn{5}{|c|}{ head of the household is in the age of $36-65$} \\
\hline With children & 75.7 & 84.1 & 86.0 & 83.6 \\
\hline Without children & 73.3 & 83.1 & 85.2 & 84.1 \\
\hline
\end{tabular}

The 65+ age group was omitted because of the low share of children in a household.

Source: own elaboration basing on EU-SILC microdata.

In the group of people under 35, the fractional test for two samples showed significant differences in the level of ownership based on having children for each of the examined periods ( $<<0.01$ in 2006, $\mathrm{p}<0.001$ in 2010, 2014, 2018). It can also be seen that these differences increased over the period considered (from $4.3 \mathrm{pp}$ in 2006 to $20.4 \mathrm{pp}$ in 2018). However, this relationship did not apply to the second age cluster. In this group, differences due to having children were not significant in any of the analyzed periods ( $p>0.05$ ). To sum up, it can be seen that, in Polish society, young people postpone the relocation to a private flat until they have children or are formally married. In the analyzed period, despite the general upward trend in homeowners, the opposite trend was observed among young people without children (increase in the percentage of tenants). This is another argument for including this variable in the household life cycle study.

Both the literature analysis and the cross-sectional data for Poland indicate that the following 
criteria are important for creating the structure of the tenure status during life cycle: age, marital status and having children. These are the criteria that determine the family life cycle, for example in consumer research. Despite the fact that the literature presents its division into many detailed phases (see: Rudnicki, 2012), a reduction in the number of analyzed classes would be beneficial to understand the idea of tenure structure changes in the life cycle of a household. Hence, the Author proposes a division into three main phases:

1. Formation stage - the head of the household is under the age of 35, he/she is not married and has no children.

2. Stabilization stage - the head of the household is:

a. between 36 and 64 years of age, except for divorced/ separated / widowed people1.

b. up to 36 years of age if he/she has children or is married.

3. Reduction stage - the head of the household is:

a. over 65 years of age,

b. divorced / separated / a widower and has not remarried (regardless of age).

Table 4 summarizes the structure of households in Poland according to the introduced classification of the household life cycle and (for comparison) in age clusters.

Household structure in Poland by life-cycle and by the age of the head of the household

Table 4

\begin{tabular}{|c|c|c|c|c|}
\hline Group & 2006 & 2010 & 2014 & 2018 \\
\hline \multicolumn{5}{|c|}{ By the life-cycle } \\
\hline Formation stage & 3.0 & 2.8 & 2.7 & 3.6 \\
\hline Stabilization stage & 61.1 & 60.6 & 57.5 & 52.0 \\
\hline Reduction stage & 35.9 & 36.7 & 39.8 & 44.4 \\
\hline \multicolumn{5}{|c|}{ By the age of the head of the household } \\
\hline under 35 & 12.6 & 11.9 & 10.7 & 10.9 \\
\hline $36-64$ & 59.6 & 61.0 & 59.1 & 54.2 \\
\hline above 65 & 27.8 & 27.1 & 30.2 & 34.9 \\
\hline
\end{tabular}

Source: own elaboration basing on EU-SILC microdata.

In the entire study period there was a strong advantage of households in the second stage in Polish society, referred to here as stabilization. The share of households at the reduction stage has been growing significantly from period to period since 2010. In 2018, it reached the level of $44.4 \%$ of all households in Poland. These changes largely resulted from the change in the age structure of households, especially the increase in the share of people aged 65+ (in 2006, this was 13.4\%, whereas in $2018-17.5 \%)$. It can also be noted that, while the share of households in the first age cluster dropped during the period under study, the share of households at the stage of formation increased, which indicates an earlier independence of young people. The relationship between the year and belonging to a family life cycle was statistically significant $\left(x^{2}, p<0.001\right)$, although the contingency coefficient was at a very low level (0.076). The differences in fractions for all stages between the years 2006 and 2018 are significant $(p<0.001)$. Significant fraction changes at any stage of the lifecycle were not observed only in 2010 ( $p>0.05$ ).

Next, corresondence analysis was shown to better ilustrate the relations between columns and rows in the cross tables, and, as a result, to indicate the relationship between them. Firstly the percentage of households at a particular stage of the life cycle and the year were used as the input variables (Fig. 2). Using this analysis, we see that the stabilization stage is relatively close to the years: 2006, 2010 and 2014, whereas in the year 2018, it is closer to the reduction stage. This is an argument for the changing structure of households in Poland according to life cycle stages.

\section{Empirical results}

The carried out research sought to an answer to the question of what the structure of the tenure status in the life cycle of households in Poland is and how it has changed was sought. According to Tab. 5, the share of households of owners in Poland generally speaking increased significantly, from 73.9 to $82.0 \%$ during the period under review (test for two fractions, $\mathrm{p}<0.001$ ). This growth was not equal in

\footnotetext{
${ }^{1}$ unless the partner lives in the household (the person started new relationship)
} 
all life cycle stages.

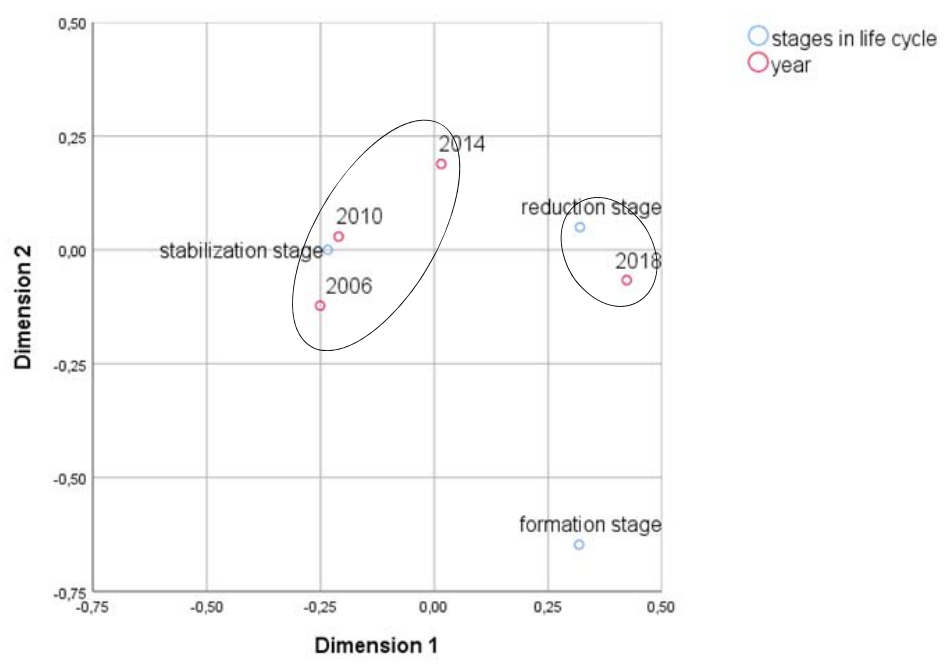

Fig. 2. Correspondence analysis for percentage of households in particular stages of the life cycle and the year. Source: own elaboration basing on EU-SILC microdata.

Table 5

Share of homeowners by stage of the household life cycle in Poland in 2006-2018

\begin{tabular}{|c|c|c|c|c|}
\hline Group & & & & 2018 \\
\hline Generally & 73.9 & 81.0 & 83.0 & 82.0 \\
\hline \multicolumn{5}{|c|}{ By the life-cycle } \\
\hline Formation stage & 53.2 & 56.1 & 50.7 & 43.0 \\
\hline Stabilization stage & 74.7 & 82.9 & 84.4 & 83.6 \\
\hline Reduction stage & 74.3 & 79.5 & 82.7 & 82.8 \\
\hline
\end{tabular}

Source: own elaboration basing on EU-SILC microdata.

A remarkable feature of Table 5 is the great disequilibrium between the owners' participation in the first and in the other groups. Households in the formation stage are less often owner-occupiers. What is more, in 2018, the number of tenants in this group exceeded the number of owners (with the total increase of owners in the Polish economy).

The relationship between the year and the percentage of owners in each stage of the life cycle was statistically significant $\left(\chi^{2}, \mathrm{p}<0.001\right)$, although weak (the contingency coefficient was 0.124$)$. The differences in fractions for all stages between 2006 and 2018 years were significant $(p<0.001)$. It should be noted, however, that a significant increase was recorded at stages 2 and 3, while a significant decrease at stage one, although it has only been taking place since 2014. Given the growing share of this group of households, it may be concluded that young people more often became independent through relocation to rented flats. This is characteristic of the period of good economic situation, the peak of which can be dated from 2018 to 2019. On the contrary, for the stabilization stage, a dynamic increase in the share of owners was recorded in the period 2006-2010. In the years 2014-2018, a slight decrease was recorded (fraction test, $\mathrm{p}>0.05$ ). Relocation trends for rented flats are observed at the stage of household reduction, these decisions are related to the disintegration of households, not to the aging process. It can be seen that, during the implementation of the Family on its own (2007-2013) program, the percentage of owners in the group to which the program was addressed increased the most (married people with children). During the implementation of the Place to Live for the Young program (starting in 2014), when co-financing covered households in the first stage, a paradoxically lower percentage of owners was recorded.

Next, correspondence analysis was used to illustrate changing relations between: the percentage of homeowners in particular life cycle stages (1st - formation stage, 2nd - stabilization stage, 3rd reduction stage) and the year (input variables). Using correspondence analysis (Fig. 3), we see that owners in the stabilization stage are relatively close to the years 2010 and 2014, when owners at 3rd 
stage are closer to 2018.

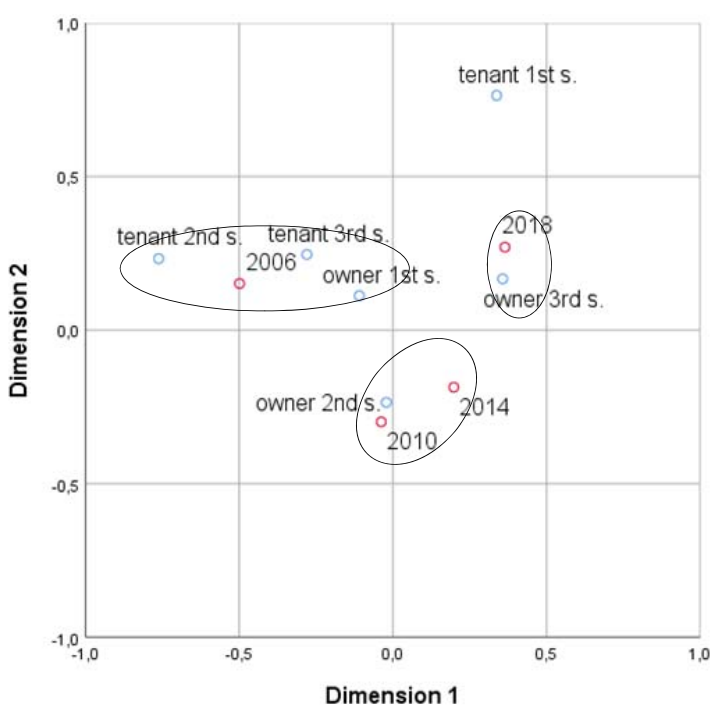

Household life stages: 1st - formation stage, 2nd -stabilization stage, 3rd - reduction stage

Fig. 3. Correspondence analysis for the the percentage of homeowners in particular life cycle stages and the year. Source: own elaboration basing on EU-SILC microdata.

Rental according to the EU-SILC methodology is divided into a market and non-market form (rental at a reduced price, free accommodation). In Poland, in the analyzed period, the share of households renting a flat at market price in general households increased from 3.2 to $4.5 \%$ (Table 6). The share of market rentals in the total number of tenants in Poland changed $(p<0.001)$ from 12 to $25 \%$. Market renting is displacing non-market forms, which is associated with changes in the ownership structure of flats (decrease in the number of Municipal Housing, flats owned by Treasury (GUS, 2019).

Table 6

Share of tenants paying market rate in all tenants in Poland in 2006-2018

\begin{tabular}{llcll}
\hline Group & $\mathbf{2 0 0 6}$ & $\mathbf{2 0 1 0}$ & $\mathbf{2 0 1 4}$ & $\mathbf{2 0 1 8}$ \\
\hline Generally & 12.2 & 12.5 & 22.7 & 25.0 \\
\hline & \multicolumn{5}{c}{ By the life-cycle } \\
\hline Formation stage & 49.0 & 47.4 & 67.1 & 70.3 \\
\hline Stabilization stage & 10.7 & 12.8 & 22.8 & 26.2 \\
\hline Reduction stage & 9.2 & 6.2 & 14.3 & 11.7 \\
\hline
\end{tabular}

Source: own elaboration basing on EU-SILC microdata.

A remarkable feature of Table 6 is a strong disproportion in the share of market tenants in the formation stage compared to others. Market rent is the dominant form of lease at the stage of family formation. Its share was significantly lower in subsequent stages of the life cycle throughout the period ( $\mathrm{p}<0.001$ ). At the same time, the share of market rent at the stabilization stage was significantly higher than at the reduction stage ( $p<0.001$ for 2010, 2014, 2018). At the same time, a change in the structure of the lease in the analyzed period is visible. The relationship between this structure in the life cycle stages and the year is significant $(\mathrm{p}<0.001)$, although it is not strong (contingency coefficient 0.186). This is characteristic of changes in the structure of both the housing status and ownership structure of flats, which usually does not record dynamic changes and is quite stable over time. It can be observed that changes in the rental structure were particularly noted in the period 2010-2014. In the years 2014-2018, the changes were smaller ( $p<0.05$ for the forming and stabilization stage and no significant differences for the forming stage).

As a next step, the correspondence analysis (Fig. 4) was carried out usingthe following as input 
variables: the percentage of tenants renting flats at market and reduced price in particular life cycle stages (Household life stages: 1st - formation stage, 2nd -stabilization stage, 3rd - reduction stage) and the year. We see that (Fig. 4) the years 2006 and 2010 are relatively close to tenants at reduced price in all stages, whereas the year 2018 is seen to be relatively close to the category of tenants at market price at the formation stage. In general, it can be seen that, for each stage of the life cycle, nonmarket rental is being replaced by the market one over the period under consideration. However, this is not so much due to preferences as due to the availability of certain forms of accommodation.

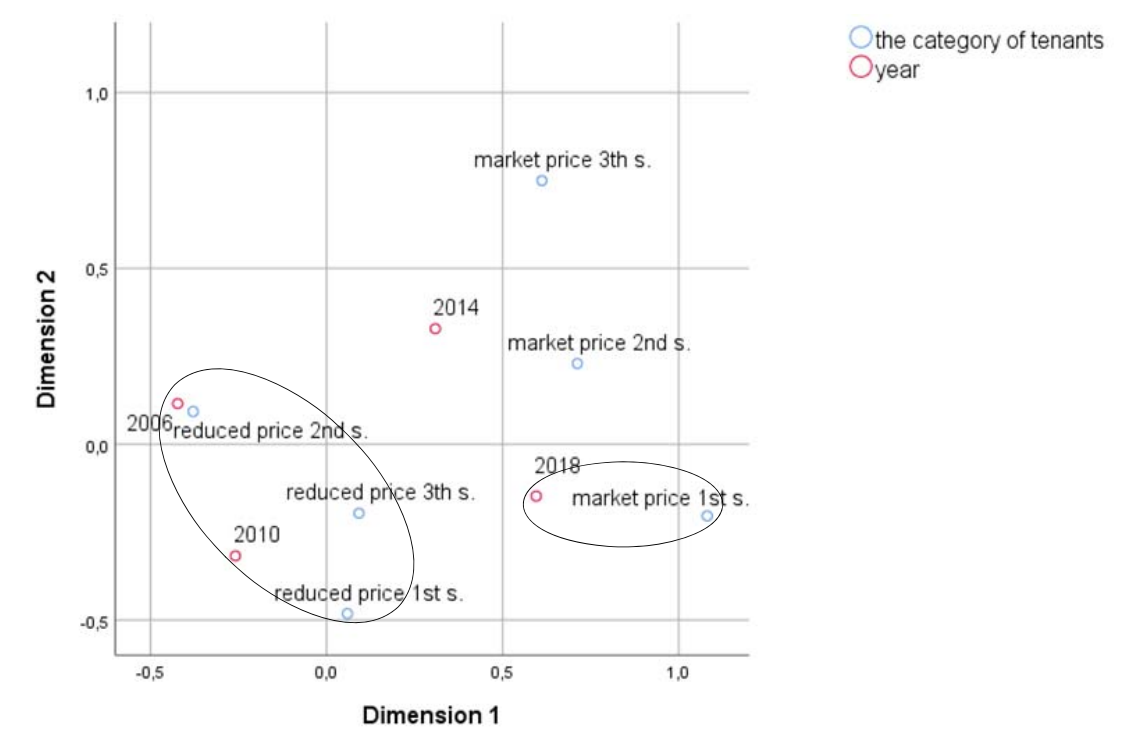

Household life stages: 1st - formation stage, 2nd-stabilization stage, $3 \mathrm{rd}$ - reduction stage

Fig. 4. Correspondence analysis for the percentage of tenants renting flats at market and reduced price in particular life cycle stages and the year. Source: own elaboration basing on EU-SILC microdata.

The last part of the analysis of the structure of the share of homeowners involved is those paying mortgage over the life cycle of households. It was not possible to list them in 2006 due to a change in the EU-SILC methodology.

Table 7

Share of homeowners paying mortgage in all homeowners in Poland in 2010-2018

\begin{tabular}{llll}
\hline Life cycle stage & $\mathbf{2 0 1 0}$ & $\mathbf{2 0 1 4}$ & $\mathbf{2 0 1 8}$ \\
\hline Generally & 6.6 & 9.7 & 10.3 \\
\hline \multicolumn{3}{c}{ By the life-cycle } \\
\hline Formation stage & 14.2 & 25.0 & 24.2 \\
\hline Stabilization stage & 9.4 & 14.4 & 16.1 \\
\hline Reduction stage & 1.3 & 2.1 & 2.2 \\
\hline
\end{tabular}

Source: own elaboration basing on EU-SILC microdata.

Generally, in the analyzed period the share of households paying mortgage among all homeowners increased from 6.6 to $10.3 \%$. The structure of borrowers in particular stages of the life cycle in the analyzed period changed $\left(\chi^{2}, \mathrm{p}<0.001\right)$, although the change was not drastic (quota coefficient 0.0122). This share was significantly higher at the household formation stage than for the remaining stages throughout the period $(\mathrm{p}<0.001)$. At the same time, these differences increased during this time. This means that more and more often, borrowers are young people, unmarried and without children. Such a high rate after 2014 may be associated with the liberalisation of credit policy. Overall, the increase in the share of borrowers at each stage was significant (fraction test, $p<0.001$ ). It concerned mainly households at the formation stage (increase by $10 \mathrm{pp}$ ) and, to a lesser extent, at the stabilization stage (increase by 6.5pp). 


\section{Discassion and conclusions}

Poles have strong preferences for being homeowners. This may result from a number of factors, including both cultural conditions and the statutory function of the flat, as well as high rental costs in relation to the cost of purchasing a flat on credit, or the inadequacy of the rental market to meet the needs of potential tenants.

It can be noted that the observed changes do not apply equally to households at particular stages of the life cycle. Paradoxically, the share of tenants is increasing among young people, unmarried and without children (formation stage), despite a significant increase in ownership in other groups. This observation could be an argument for confirming the statement that rent in Poland is treated as a temporary form of satisfying housing needs. The changing share of tenants in particular life stages of households could indicate that fewer and fewer people choose to be lifelong tenants. What is more, events such as marriage and childbirth have an increasingly strong impact on the housing situation. It would be beneficial to observe households decisions in subsequent years, which is not possible basing on EU-SILC data (even when the same household is interviewed for several years, they are not identifiable).

Since 2018, there are more tenants than owners among the young and unmarried, and people without children. These groups of people have specific characteristics when it comes to the housing situation, which is associated with the formation of the household. They often postpone important decisions such as buying a flat as well as permanently settling down. On the other hand, such changes could be connected with young people becoming more independent. Relocation to private housing among people aged 35 and younger is related to motherhood (similar: Andersen, 2011). This, in turn, may indicate a lack of preferences among young people at the household formation stage towards ownership, e.g. in order to maintain professional and life mobility, as well as the lack of social pressure to buy a flat, and a lesser need for a sense of stability.

In many countries, the crisis undermined existing residential patterns through changes in the financial market (including access to external financing for the purchase of housing) and unfavourable labour market processes (Lennartz et al., 2016). As a result, housing opportunities for young people have become increasingly dependent on intergenerational transfers and, generally, family background; this could hinder social mobility and exacerbate inequality (Coulter, 2018). In Poland, also after a period of economic crisis, there was a decrease in ownership among people at the stage of household formation. However, the fact that this decline intensified during the boom (2018) indicates that this is not the effect of the economic crisis. On the other hand, the share of young people living with their parents and postponing becoming independent was not analysed in the research. Such an analysis could provide us with a broader view of the changes observed.

Among households at the stage of stabilization (married persons, with children or aged 36-64) the share of owners is experiencing the highest growth. Tenants are dominated by non-market tenancy, in contrast to the formation stage, where there is a strong dominance ( $70 \%$ of the lease) of market lease forms. At the same time, there is no tendency in Poland to relocate to a rented flat at the stage of household reduction. Small changes result not from age, but from the break-up of the family as a result of a divorce.

The relationship between the life cycle of a household and the change in housing status is somewhat characteristic of a given economy, conditioned both historically and culturally. For example, Bayrakdar et al. (2019) found first-time homeownership in Britain to be tightly synchronized with partnership formation, whereas in Germany, this transition usually occurs later in the life cycle and is more closely associated with the arrival of children. These differences are mainly explained by weaker aspirations and weaker incentives to enter homeownership in Germany (S. Bayrakdar et al. 2019). Poles seem to be more similar to the British in terms of aspirations to live in a private flat. Both, strong aspirations to be an owner (Rubaszek \& Czerniak, 2017) and the unfavorable relationship of rent to apotential loan installment increase the desire to quickly enter into the ownership of a flat after moving to the stage of household stabilization.

Additional information: The source of the data is the Central Statistical Office, The European Union Statistics on Income and Living Conditions (EU-SILC). The Central Statistical Office is not liable for the data and conclusions presented in the publication.

\section{Funding}


This research was funded by Polish National Science Centre (NCN) Grant 2018/31/N/HS4/02333.

\section{References}

Andersen, H. S. (2011). Motives for Tenure Choice during the Life Cycle: The Importance of NonEconomic Factors and Other Housing Preferences, Housing. Theory and Society, 28(2), 183-207.

Andrews, D., \& Sánchez, A. C. (2011). Drivers of Homeownership Rates in Selected OECD Countries. OECD Economics Department Working Papers, 849, 1-44.

Arrondel, L., Badenes, N., \& Spadaro, A. (2010). Consumption and Investment Motives in Housing Wealth Accumulation of Spanish Households. Social Science Research Network (SSNR) Working Paper, 1-21. https://doi.org/10.2139/ssrn.1597126

Barrios, V. E., Colom, M. C., \& Molés, M. C. (2013). Life cycle and housing decisions: A comparison by age cohorts. Applied Economics, 45(32), 4556-4568. https://doi.org/10.1080/00036846.2013.795276

Bayrakdar, S., Coulter, R., Lersch, Ph., \& Vidal, S. (2019). Family formation, parental background and young adults' first entry into homeownership in Britain and Germany. Housing Studies, 34(6), 974996, https:// doi.org/10.1080/02673037.2018.1509949

Bazyl, M., (2009). Factors influancing tenure choice in European countries. Journal Central European Journal of Economic Modelling and Econometrics, 1(4), 371-387.

Byrne, D., Duffy, D., \& Fitzgerald, J. (2018). Household Formation and Tenure Choice: Did the Great Irish Housing Bust Alter Consumer Behaviour? The Economic and Social Review, 39(3), 287-317.

Capeau, B., Decoster, A., \& Vermeulen, F. (2003). Homeownership and the Life Cycle: an Ordered Logit Approach. Working Papers of Department of Economics, 308.

Coulter R., (2018). Parental background and housing outcomes in young adulthood. Housing Studies, 33(2), 201-223. https://doi.org/10.1080/02673037.2016.1208160

Cuerpo, C., Kalantaryan, S., \& Pontuch, P. (2014). Rental Market Regulation in the European Union, European Economy. Economic Papers, 515, 1-52. https://doi.org/10.2765/69909

Dieleman F. D., \& Everaers, P. C. J. (1994). From renting to owning: Life course and housing market circumstances. Housing Studies, 9(1), 11-25. https:// doi.org/10.1080/02673039408720772

Disney, R., Henley, A., \& Gallagher, T. 1995, Housing assets and savings behavior among the elderly in Great Britain, Institute for Fiscal Studies Working Paper, no. 22, pp. 353-404.

Edgar, B., Filipowić, M., \& Dandolova, I. (2007). Home Ownership and Marginalisation. European Journal of Homelessness, 1, 141-160.

Eurostat. (2020). http://appsso.eurostat.ec.europa.eu/nui/submitViewTableAction.do, Access of the day: $17.03 .2020 \mathrm{r}$.

Feijten, P. (2005). Union dissolution, unemployment and moving out of homeownership. European Sociological Review, 21(1), 59-71. https://doi.org/10.1093/esr/jci004

Flynn, L. (2017). Delayed and depressed: From expensive housing to smaller families. International Journal of Housing Policy, 17(3), 374-395. https:// doi.org/10.1080/14616718.2016.1241936

GUS. (2019). Gospodarka mieszkaniowa w $2018 \mathrm{r}$. [Housing economy in Poland in 2018].

Gyourko, J., \& Linneman, P. (1997). The changing influences of education, income, family structure, and race on homeownership by age over time. Journal of Housing Research, (8), 1-25.

Kemp, P.A., \& Keoghan, M. (2001). Movement Into and Out of the Private Rental Sector in England. Housing Studies, 16(1), 21-37. https://doi.org/10.1080/02673030020015100

Kendig, H. L. (1984). Housing careers, life cycle and residential mobility: Implications for the housing market. Urban Studies, 21(3), 271-283. https://doi.org/10.1080/00420988420080541

Lennartz, Ch., Arundel, R., \& Ronald, R. (2016). Younger Adults and Homeownership in Europe Through the Global Financial Crisis. Population Space and Place, 22(8), 823-835. https://doi.org/10.1002/psp.1961

Lux, M., \& Sunega, P. (2014). Public Housing in the Post-Socialist States of Central and Eastern Europe. Housing Studies, 29(4), 501-519. https://doi.org/10.1080/02673037.2013.875986

Matel, A. (2019). Czynniki różnicujące status mieszkaniowy gospodarstw domowych w Polsce [Factors differentiating tenure status of households in Poland], Rozprawa doktroska, https://repozytorium.uwb.edu.pl/jspui/handle/11320/8742

McKee, K. (2012). Young people, homeownership and future welfare. Housing Studies, 27(6), 853-862. https://doi.org/10.1080/02673037.2012.714463 
McKee, K., Moore, T., Soaita A., \& Crawford, J. (2017). "Generation Rent" and the fallacy of choice. International Journal of Urban and Regional Research, 41(2), 318-333.

Methodological Guidelines and Description of EU-SILC Target Variables. (2015). European Commission, Eurostat.

Mulder, C. H., \& Wagner, M. (1998). First-time homeownership in the family life course: A West German-Dutch comparison. Urban Studies, 35(4), 687-713.

Rubaszek, M. (2019). Private rental housing market underdevelopment: life cycle model simulations for Poland, Baltic Journal of Economics, 9(12), 334-358. https://doi.org/10.1080/1406099X.2019.1679558

Rubaszek, M., \& Czerniak, A. (2017). Preferencje Polaków dotyczące struktury własnościowej mieszkań: opis wyników ankiety [Housing tenure preferences of Poles: the survey results]. Bank $i$ kredyt, 48(2), 197-234.

Rudnicki, L. (2012). Zachowania konsumentów na rynku [Consumers' behavior on the market]. Polskie Wydawnictwo Ekonomiczne.

Strączkowski, Ł., \& Boruta, M. (2018). Warunki i decyzje mieszkaniowe seniorów na lokalnym rynku nieruchomości [Seniors' Housing Conditions and Their Decisions on the Local Housing Market]. Zeszyty Naukowe Uniwersytetu Ekonomicznego w Krakowie, 3(975), 69-81.

Thomas, M., \& Mulder, C. H. (2016). Partnership patterns and homeownership: A cross-country comparison of Germany, the Netherlands and the United Kingdom. Housing Studies, 31(8), 935-963. https:// doi.org/10.1080/02673037.2016.1164832

Xhignesse, G., Bianchet, B., Cools, M., Gathon, H. J., Jurion, B., \& Teller, J. (2014). Which are the determinants of homeownership?A logit analysis for the case of Belgium. European Network for Housing Research Conference, 1-16. Edinburgh. 